\title{
Molecular characterization and genetic diversity of potato cultivars using SSR and RAPD markers
}

\author{
Elizângela Almeida Rocha ${ }^{1}$, Luciano Vilela Paiva ${ }^{2 *}$, Humberto Henrique de Carvalho ${ }^{3}$, and Claudia Teixeira Guimarães ${ }^{4}$
}

Received 30 July 2009

Accepted 16 November 2009

\begin{abstract}
This study aimed to evaluate the genetic diversity and identify potato cultivars by RAPD and SSR markers. The genomic DNA of 16 potato cultivars was amplified with 25 RAPD primers that generated 92 polymorphic bands and 20 SSR primer pairs that produced 136 polymorphic bands. The dendrograms generated by cluster analysis distinguished the cultivars genetically although the dendrograms were not correlated in the comparison of the two markers used. The PIC values demonstrated the high information content of the primers used and 16 potato varieties were identified based on six RAPD primers and three SSR primer pairs. Thus, by means of RAPD and SSR markers the genetic diversity was assessed and the 16 commercial potato cultivars analyzed in this study were identified.
\end{abstract}

Key words: Solanum tuberosum, RAPD, microsatellites, genetic diversity.

\section{INTRODUCTION}

The introduction and development of new potato cultivars (Solanum tuberosum L.) has been an important strategy to increase crop productivity of this important staple food, fourth after rice, wheat and corn. Potato is grown worldwide, and in some countries the consumption is around 75-95 kg per capita per year (Fontes 2005).

Today, over 7,500 different potato varieties are produced around the world (Hamester and Hills 2003). However, due to loss of genotypes during the journeys that brought potato to Europe, due to diseases and to the consequent domestication to long-day photoperiods, the genetic basis became narrow, making the identification by morphological markers difficult (Harris 1978, Ross 1986). Thus, reliable methods must be applied that can correctly identify cultivars to assess the genetic diversity in the potato germplasm. Indeed, advances in molecular techniques have enabled the study of genetic variability at the DNA level, which has significantly increased the accuracy in assessing the genetic diversity and identifying cultivars.

Techniques to discriminate and identify potato cultivars have been widely applied in research and breeding programs. Information on the genetic diversity allows the organization of the variability in the germplasm, assisting parent selection and paving the way to genetic gains. The characterization of genetic diversity is also important for

\footnotetext{
${ }^{1}$ Universidade Federal de Minas Gerais, Instituto de Ciências Biológicas, Departamento de Bioquímica e Imunologia, Avenida Antônio Carlos 6627, Bairro São Luiz, 31.270-901, Belo Horizonte, MG, Brazil.

${ }^{2}$ Universidade Federal de Lavras, Biotecnologia Vegetal, CP 3037, 37.200-000, Lavras, MG, Brazil. *E-mail: luciano@ufla.br.

${ }^{3}$ Universidade Federal de Viçosa, Departamento de Fisiologia Vegetal, 36.571-000, Viçosa, MG, Brazil.

${ }^{4}$ Embrapa Milho e Sorgo, Rodovia MG 424, km 65, 35.701-970, Sete Lagoas, MG, Brazil.
} 
cultivar protection, mainly of potato tuber seed (Ford and Taylor 1997) as well as to ensure the trademark and intellectual property rights (Coombs et al. 2004).

Molecular markers have become important tools in studies of genetic diversity (Bered et al. 2005), due to the high resolution and reliability in the identification of cultivars. They are also applied in the genetic characterization of potato (Ford and Taylor 1997, Schneider and Douches 1997). RAPD (Random Amplified Polymorphic DNA) markers have the advantage of detecting polymorphism simply and quickly (Demeke et al. 1996), while SSR (simple sequence repeat) markers or microsatellites provide high reproducibility and genetic informativeness. Both markers have been used in the molecular characterization of potato cultivars (Coombs et al. 2004) as well as of other species, e.g., soybean (Garcia et al. 2007).

The purpose of this study was to evaluate the genetic diversity in 16 potato cultivars that are being made available to potato growers in Brazil, and to develop a molecular profile using RAPD and SSR markers.

\section{MATERIAL AND METHODS}

The company Multiplanta Tecnologia Vegetal Ltd. provided 16 potato cultivars (Solanum tuberosum L.) for this study (Table 1). Three tubers of each cultivar were planted in pots and maintained in a greenhouse until after leaf formation and then taken to the Central Laboratory of Molecular Biology (LCBM), Federal University of Lavras, for molecular analysis. The CTAB method was used for leaf DNA extraction, as proposed by Murray and Thompson (1980) with modifications. The extracted DNA was quantified with a fluorometer (Hoefer DQ-200) and diluted in TE buffer pH 8.0 (1 mM Tris, $0.1 \mathrm{mM}$ EDTA) to working concentrations according to the marker.

The RAPD reactions were performed in a final volume of $12 \mu \mathrm{L}$ containing $10 \mathrm{ng}$ DNA, $20 \mathrm{mM}$ Tris-HCl pH 8.4, $50 \mathrm{mM} \mathrm{KCl}, 250 \mu \mathrm{M}$ of each dNTP, $2.5 \mathrm{mM} \mathrm{MgCl}_{2}, 0.2 \mathrm{mM}$ primer and $1 \mathrm{U}$ Taq DNA polymerase. Thirty-six randomly selected RAPD primers from Operon Technologies (Alameda, CA, USA) were used. The amplification reactions were carried out in a Master thermocycler (Eppendorf, Hamburg, Germany), with an initial denaturation temperature of $95^{\circ} \mathrm{C}$ for 1 minute, followed by 34 amplification cycles consisting of three steps: $94^{\circ} \mathrm{C}$ for $10 \mathrm{~s}, 36^{\circ} \mathrm{C}$ for 30 s and $72^{\circ} \mathrm{C}$ for $30 \mathrm{~s}$. After 34 cycles, the samples were subjected to a final step of $7 \mathrm{~min}$ at $72{ }^{\circ} \mathrm{C}$.
Table 1. Potato varieties used in the study of genetic variability with RAPD and SSR markers

\begin{tabular}{lll}
\hline \multicolumn{1}{c}{ Cultivars } & \multicolumn{1}{c}{ Parents } & \multicolumn{1}{c}{ Origin } \\
\hline Ágata & BM 52.72 x Sirco & Geerstsema Zaden B.V. - (Netherlands) \\
Asterix & Cardinal x SVP Ve 709 & HZPC - (Netherlands) \\
Atlantic & B 5141-6 (Lenape) $\times$ Wauseon & Maine Department Agriculture - (USA) \\
Casteline & Safrane $\times$ 85F276.5 & Bretagne Plants - (France) \\
Chipie & Pilgrin x (Saturna x Pentland Dell) & Station de Recherche du Comité Nord - (France) \\
Colorado & Toridon x (Desirée x Pentland Dell) & Station de Recherche du Comité Nord et G.I.P.T. (France) \\
Cupido & W 7222496 x Estima & Meijer Seedpotoes \& Research B.V. (Netherlands) \\
Éden & Eole x Pentland Dell & Bretagne Plants - (France) \\
Emeraude & Estima x INRA 75.36.45 & Bretagne Plants - (France) \\
Floriane & 85K102.4 x Europa & Bretagne Plants - (France) \\
Florice & Fanette x INRA 72.68.5 & Station de Recherche du Comité Nord - (France) \\
Isabel & Nicola x Tenor & Grocep - (France) \\
Monalisa & Bierma A 1287 x Colmo & H.Z.P.C. - (Netherlands) \\
Mondial & Spunta x SVP Ve 66.29.5 & D. Biemond - (Netherlands) \\
Naturella & Sirco x Pentland Squire & Bretagne Plants - (France) \\
Oceania & Astarte x Thomana & Bretagne Plants et Coopagri - (France) \\
\hline
\end{tabular}

The amplified fragments were electrophoresed on $1.2 \%\left(\mathrm{w} \mathrm{V}^{-1}\right)$ agarose gel at $100 \mathrm{~V}$ in TAE buffer $(0.001 \mathrm{M}$ EDTA, pH 8.0; 0.04 M TRIS, pH 8.0; 0.02 M acetic acid) for an hour and a half. After electrophoresis the gel was stained with ethidium bromide $\left(0.5 \mathrm{mg} \mathrm{mL}^{-1}\right)$ for $30 \mathrm{~min}$ and photographed under ultraviolet light with an EDAS 290 Kodak $^{\circledR}$ Electrophoresis Documentation and Analysis System. To minimize the low RAPD reproducibility, three clones of each genotype were used as replications for each primer, considering only the bands present or absent in the three clones.

For the SSR reactions, 21 primer pairs were used. The amplification reactions were performed in a final volume of 10 ìL containing 20 ng DNA, 10 mM Tris-HCl $\mathrm{pH}$ 8.6, $50 \mathrm{mM} \mathrm{KCl}, 0.1 \%$ gelatin, $2 \mathrm{mM} \mathrm{MgCl}_{2}, 0.25 \mathrm{mM}$ of each dNTP, $1 \mathrm{U}$ Taq DNA polymerase, and $0.2 \mathrm{mM}$ of each primer. The reactions were carried out on a Gradient Master thermocycler (Eppendorf, Hamburg, Germany), with an initial denaturation temperature of $95^{\circ} \mathrm{C}$ for 2 min followed by 34 amplification cycles consisting of three steps: $94^{\circ} \mathrm{C}$ for $20 \mathrm{~s}$, followed by the primer annealing temperature (described in Table 3) for $20 \mathrm{~s}$ and $72{ }^{\circ} \mathrm{C}$ for $20 \mathrm{~s}$. After 34 cycles, the samples were subjected to a final extension step for 4 min at $72{ }^{\circ} \mathrm{C}$.

The amplified fragments were separated on $10 \%$ polyacrylamide gel by electrophoresis at $200 \mathrm{~V}$ in TBE buffer (500 mM EDTA pH 8.0, 1M TRIS pH 8.0, 89 mM boric acid) for two hours. Thereafter the gel was silver nitrate-stained (0.2\%) and visualized in the Eagle Eye Gel Documentation System (Stratagene, La Jolla, CA, USA). Three replications for each cultivar were used as well for the SSR markers, to confirm the banding pattern of all plants analyzed.

Since potato is a species of polyploid origin, the bands generated by SSR markers were not considered 
EA Rocha et al.

allelic but evaluated as dominant markers, so the data were considered binary. Thus, to evaluate the results of SSR markers, each amplified fragment was considered as one locus, as well as the bands obtained by RAPD markers. The binary matrices were constructed based on band presence or absence designated by 1 (one) and 0 (zero), respectively. The genetic similarity matrix of the 16 potato cultivars was calculated using the Jaccard coefficient (Anderberg 1973) and based on the estimates of genetic similarity dendrograms by the unweighted pair-group method using arithmetic averages (UPGMA). To check the clustering consistency, the cophenetic correlation was calculated (Manly 1997). All stages of the analysis of genetic diversity were performed using software NTSYS-pc version 2.1 (Rohlf 2000). Each group was verified by bootstrap analysis using the program BOOD (Coelho 2000) to verify the consistency of each dendrogram node in 1000 resamplings. To check whether the number of markers used was sufficient, the optimum number of RAPD and SSR markers was calculated using GENES software (Cruz 2001) with 10 samples per simulation plus two markers. The correlation values, the sum of squared deviations (SSD) and of stress (S) between the original matrix and the samples were used to evaluate the optimal number of polymorphic bands according to Dias (1998) and Kruskal (1964). The polymorphic information content (PIC) was also calculated, determined by the equation: $\mathrm{PIC}=1-\Sigma_{\mathrm{i}} \cdot \Sigma_{\mathrm{j}} \cdot \mathrm{pij}^{2}$, where pij is the frequency of allele p of locus i in primer $\mathrm{j}$ (Rafalski et al. 1996).

\section{RESULTSAND DISCUSSION}

Of the 36 RAPD primers tested, 25 were selected based on the quality and repeatability of the amplified bands. Altogether, 185 bands were obtained, with an average of 7.4 bands per primer, of which 92 were polymorphic. The polymorphic bands ranged from one in the primers OPX02, OPG17, OPP12, OPM02, OPM20 and OPM12 to eight bands in primer OPJ13. The PIC value ranged from 0.94 for primer OPG13 to 0.12 for OPX02 (Table 2). Primer OPG13 was considered very informative due to its high efficiency in detecting polymorphisms among the evaluated plants.

The number of polymorphic bands was considered appropriate to assess the genetic divergence, since the analyses of the optimal number of markers indicated that with 75 polymorphic bands, the correlation with the genetic distance matrix of all markers was 0.94 , the sum of squared deviations (SSD) was 0.086 and the stress value (S) was
Table 2. RAPD primers, with their respective base sequences, PIC (Polymorphic Information Content) and number of polymorphic markers in 16 potato cultivars

\begin{tabular}{cccc}
\hline Primer & $\begin{array}{c}\text { Sequence } \\
\text { (5'-3) }\end{array}$ & PIC & $\begin{array}{c}\text { Number of } \\
\text { polymorphic bands }\end{array}$ \\
\hline OPG08 & TCACGTCCAC & 0.88 & 6 \\
OPG10 & AGGGCCGTCT & 0.82 & 4 \\
OPG13 & CTCTCCGCCA & 0.94 & 7 \\
OPG17 & ACGACCGACA & 0.49 & 1 \\
OPG19 & GTCAGGGCAA & 0.84 & 4 \\
OPJ13 & CCACACTACC & 0.92 & 8 \\
OPM02 & ACAACGCCTC & 0.49 & 1 \\
OPM05 & GGGAACGTGT & 0.76 & 3 \\
OPM07 & CCGTGACTCA & 0.75 & 3 \\
OPM12 & GGGACGTTGG & 0.47 & 1 \\
OPM19 & GTCCGTACTG & 0.89 & 6 \\
OPM20 & AGGTCTTGGG & 0.37 & 1 \\
OPN02 & ACCAGGGGCA & 0.90 & 6 \\
OPP03 & CTGATACGCC & 0.84 & 5 \\
OPP04 & CTGATACGCC & 0.85 & 5 \\
OPP08 & ACATCGCCCA & 0.68 & 2 \\
OPP12 & AAGGGCGAGT & 0.37 & 1 \\
OPP13 & GGAGTGCCTC & 0.89 & 6 \\
OPU14 & TGGGTCCCTC & 0.80 & 4 \\
OPX02 & TTCCGCCACC & 0.12 & 1 \\
OPX04 & CCGCTACCGA & 0.89 & 6 \\
OPX07 & GAGCGAGGCT & 0.58 & 2 \\
OPX08 & CAGGGGTGGA & 0.81 & 3 \\
OPX09 & GGTCTGGTTG & 0.79 & 3 \\
OPX10 & CCCTAGACTG & 0.77 & 3 \\
\hline & & & \\
\hline
\end{tabular}

0.045, suggesting high consistency in the association of the matrices, according to Kruskal (1964). This indicated that the genetic diversity estimates based on RAPD markers were reliable.

Average genetic similarity between pairs of plants was $0.61 \pm 0.02$, with a range of $0.73-0.38$. In the resulting dendrogram (Figure 1A) the cophenetic correlation $\left(r_{c}\right)$ was 0.86 , a value considered high compared with the minimum $\left(r_{c}=0.6\right)$ suggested by Manly (1997). In his studies with Indian potato cultivars, Chakrabarti et al. (2006) found a value of $r_{c}=0.92$ for the cophenetic correlation matrix, suggesting that the level of association found by the similarity dendrogram was good.

By the dendrogram based on RAPD markers the cultivars were allocated according to the place of origin, 
Molecular characterization and genetic diversity of potato cultivars using SSR and RAPD markers

Table 3. SSR primers, their respective base sequences, annealing temperature (Ta), PIC (Polymorphic Information Content) and polymorphism (NBP) obtained in 16 potato cultivars

\begin{tabular}{|c|c|c|c|c|c|c|}
\hline Primer & Replication & Sequence (Forward) & Sequence (Reverse) & $\mathrm{Ta}\left({ }^{\circ} \mathrm{C}\right)$ & PIC & NBP \\
\hline StI046 & $(\mathrm{GAT})_{\mathrm{n}}$ & CAGAGGATGCTGATGGACCT & GGAGCAGTTGAGGGCTTCTT & 54 & 0.97 & 18 \\
\hline STM1052 & $(\mathrm{AT})_{14} \mathrm{GT}(\mathrm{AT})_{4}(\mathrm{GT})_{6}$ & CAATTTCGTTTTTTCATGTGACAC & ATGGCGTAATTTGATTTAATACGTAA & 54 & 0.96 & 15 \\
\hline STPoAc58 & $(\mathrm{TA})_{13}$ & TTGATGAAAGGAATGCAGCTTGTG & ACGTTAAAGAAGTGAGAGTACGAC & 57 & 0.95 & 12 \\
\hline STM1016 & $(\mathrm{TCT})_{9}$ & TTCTGATTTCATGCATGTTTCC & ATGCTTGCCATGTGATGTGT & 53 & 0.95 & 12 \\
\hline STM0031 & $(\mathrm{AC})_{5} \ldots(\mathrm{AC})_{3}(\mathrm{GCAC})(\mathrm{AC})_{2}(\mathrm{GCAC})_{2}$ & CATACGCACGCACGTACAC & TTCAACCTATCATTTTGTGAGTCG & 57 & 0.90 & 6 \\
\hline StI031 & $(\mathrm{TCA})_{\mathrm{n}}$ & AGGCGCACTTTAACTTCCAC & CGGAACAAATTGCTCTGATG & 54 & 0.92 & 8 \\
\hline STM2013 & $(\mathrm{TCTA})_{6}$ & TTCGGAATTACCCTCTGCC & AAAAAAAGAACGCGCACG & 55 & 0.90 & 7 \\
\hline STWAX-2 & $(\mathrm{ACTC})_{5}$ & CCCATAATACTGTCGATGAGCA & GAATGTAGGGAAACATGCATGA & 53 & 0.92 & 8 \\
\hline STCAAS3 & $(\mathrm{AAG})_{7}$ & AATTCATGTTTGCGGTACGTC & ATGCAGAAAGATGTCAAAATTGA & 60 & 0.92 & 8 \\
\hline STM1104 & $(\mathrm{TCT})_{5}$ & TGATTCTCTTGCCTACTGTAATCG & CAAAGTGGTGTGAAGCTGTGA & 57 & 0.88 & 5 \\
\hline STM1106 & $(\mathrm{ATT})_{13}$ & TCCAGCTGATTGGTTAGGTTG & ATGCGAATCTACTCGTCATGG & 55 & 0.88 & 6 \\
\hline STM0037 & $(\mathrm{TC})_{5}(\mathrm{AC})_{6} \mathrm{AA}(\mathrm{AC})_{7}(\mathrm{AT})_{4}$ & AATTTAACTTAGAAGATTAGTCTC & ATTTGGTTGGGTATGATA & 53 & 0.87 & 5 \\
\hline STGBSS & $(\mathrm{TCT})_{9}$ & AATCGGTGATA AATGTGAATGC & ATGCTTGCCATGTGATGTGT & 53 & 0.89 & 6 \\
\hline STM1031 & $(\mathrm{AT})_{13}$ & TGTGTTTGTTTTTCTGTAT & AАTTCTATCCTCATCTCTA & 55 & 0.85 & 5 \\
\hline STM2022 & $(\mathrm{CAA})_{3} \ldots(\mathrm{CAA})_{3}$ & GCGTCAGCGATTTCAGTACTA & TTCAGTCAACTCCTGTTGCG & 53 & 0.84 & 4 \\
\hline STM0030 & Composto $(\mathrm{GT} / \mathrm{GC})(\mathrm{GT})_{8}$ & AGAGATCGATGTAAAACACGT & GTGGCATTTTGATGGA TT & 53 & 0.85 & 5 \\
\hline STM0019 & $\begin{array}{l}(\mathrm{AT})_{7}(\mathrm{GT})_{10}(\mathrm{AT})_{4} \\
(\mathrm{GT})_{5}(\mathrm{GC})_{4}(\mathrm{GT})_{4}\end{array}$ & AATAGGTGTACTGACTCTCAATG & TTGAAGTAAAAGTCCTAGTATGTG & 50 & 0.21 & 1 \\
\hline StI005 & $(\mathrm{ACA})_{\mathrm{n}}(\mathrm{GCA})_{\mathrm{n}}$ & CTAATTTGATGGGGAAGCGA & CGGÁGATA AAACCCAAGTCC & 54 & 0.50 & 1 \\
\hline STM1049 & $(\mathrm{ATA})_{6}$ & CTACCAGTTTGTTGATTGTGGTG & AGGGACTTTAATTTGTTGGACG & 57 & 0.68 & 2 \\
\hline STU6SNRN & $(\mathrm{TGG})_{5}$ & GAAGTTTTATCAGAATCC & ATCACCTCATCAGCAATC & 50 & 0.50 & 1 \\
\hline
\end{tabular}

and morphological characteristics of the parents. The similarity of the cultivars Floriane and Elizabeth was highest (73\%), which are both from France, suitable for domestic use and baking, and improved by Bretagne Plants. The similarity index of the cultivars Ágata and Colorado (73\%) which have tubers with yellow flesh and moderate virus Y resistance was the same.

The similarity of $70 \%$ between the cultivars Mondial and Asterix, both developed in the Netherlands, is justified by the common parent SVP Ve. The similarity of the cultivars Casteline and Emeraude, improved by Bretagne Plants in France, with the common traits elongated oval tubers with yellowish skin, is also $70 \%$ and the bootstrap $60 \%$.

The cultivars Florice and Casteline, with 65\% similarity, have the common parent INRA and the cultivars Chipie and Eden, with 67\% similarity, have the parent Pentland Dell in common, besides having been developed in France. The cultivar Atlantic on the other hand was far from the other cultivars, probably due to the origin in the United States and different parent cultivars.

With six RAPD primers (OPG08, OPJ13, OPG10, OPM19, OPG13, and OPP04) it was possible to differentiate all 16 potato cultivars evaluated in this study. These primers were selected for their high PIC values ranging from 0.82 for primer OPG10 to 0.94 for primer OPG13. The cultivar identification using RAPD markers is well-documented in studies of molecular characterization (Bianchi et al. 2003, Crochemore et al. 2004). Fingerprinting based on this marker type was used for identification and characterization of potato cultivars in North America (Sosinski and Douches 1996), Australia (Ford and Taylor 1997) and India (Chakrabarti et al. 1998).

Of the 21 SSR primer pairs evaluated, polymorphism among the cultivars analyzed was detected in 20, which generated well-defined and reproducible bands. With an average of 6.8 polymorphic fragments per primer, 136 polymorphic fragments were amplified. The number of polymorphic bands ranged from one for the primers STM0019, STM1049 and STU6SNRN to 18 for primer StI046 (Table 3). In similar studies, there was great variation in the number of SSR primers used and the polymorphisms generated, but the polymorphism level was usually high for potato cultivars (Coombs et al. 2004, Ghislain et al. 2006), since the ploidy of the cultivated genotypes is essentially tetraploid.

SSR markers revealed high polymorphism levels among the 16 potato cultivars analyzed. According to Provan et al. (1996), this is particularly relevant because in tetraploids, each plant may contain between one and four different alleles in one locus. In this study, when only one microsatellite locus was considered, polymorphic bands 
ranged from 2 to 18 . The informativeness of the SSR primers ranged from 0.97 for primer StI046 to 0.21 for primer STM0019 (Table 3). Similarly, the PIC values in other studies of potato varieties also varied according to the primers tested, evidencing high information and polymorphism levels detected by SSR markers (Norero et al. 2002, Feingold et al. 2005).

The 136 polymorphic bands were considered adequate in the assessment of genetic diversity, since from 125 polymorphic bands there was a correlation of 0.97 between genetic distance matrices compared with the matrix generated by the 136 polymorphic bands, the SSD was 0.03 and S value was 0.044 . This result indicated that the genetic diversity estimates in plants based on SSR markers were safe and reliable.

Average genetic similarity among cultivars was 0.56 , with a range from 0.46 to 0.72 . The dendrogram (Figure 1B) showed a value of cophenetic correlation of 0.68 , indicating a reasonable representation of the similarity matrix generated by Jaccard's coefficient.

The genetic similarity was highest between the cultivars Cupido and Emeraude (0.72) and between Ágata and Naturela (0.72). The cultivars Cupid and Emeraude have the parent Estima and Ágata and Naturela have the parent Sirco in common, justifying the high genetic similarity among them. Similarity was lowest between the cultivars and Oceania and Florice (0.46), both from France.

With only three SSR primers (STM0031, STM1106 and STM2013) all 16 potato cultivars evaluated could be differentiated, since the PIC values of these primers were high, ranging from 0.88 for primer STM1106 to 0.90 for primer STM0031. Amplification with primer STM0031 generated 14 different molecular patterns, distinguishing all cultivars except for Éden, Emeraude, Isabel, and Florice. The cultivars Éden and Emeraude were then differentiated by the molecular patterns obtained by primer STM1106, and cultivars Isabel and Florice by primer STM2013. In similar studies, the microsatellite markers were quite promising in the identification of potato cultivars (Ghislain et al. 2000, Ashkenazi et al. 2001, Norero et al. 2002).

The results obtained with RAPD and SSR markers were not consistent in this study, justified by the low correlation (0.17) between the similarity matrices. Similarly, Ghislain et al. (2006) found that the dendrograms generated by RAPD and SSR markers in potato were not correlated and Milbourne et al. (1997) observed a low correlation between the analysis of genetic diversity using RAPD, AFLP and SSR markers in the same species.

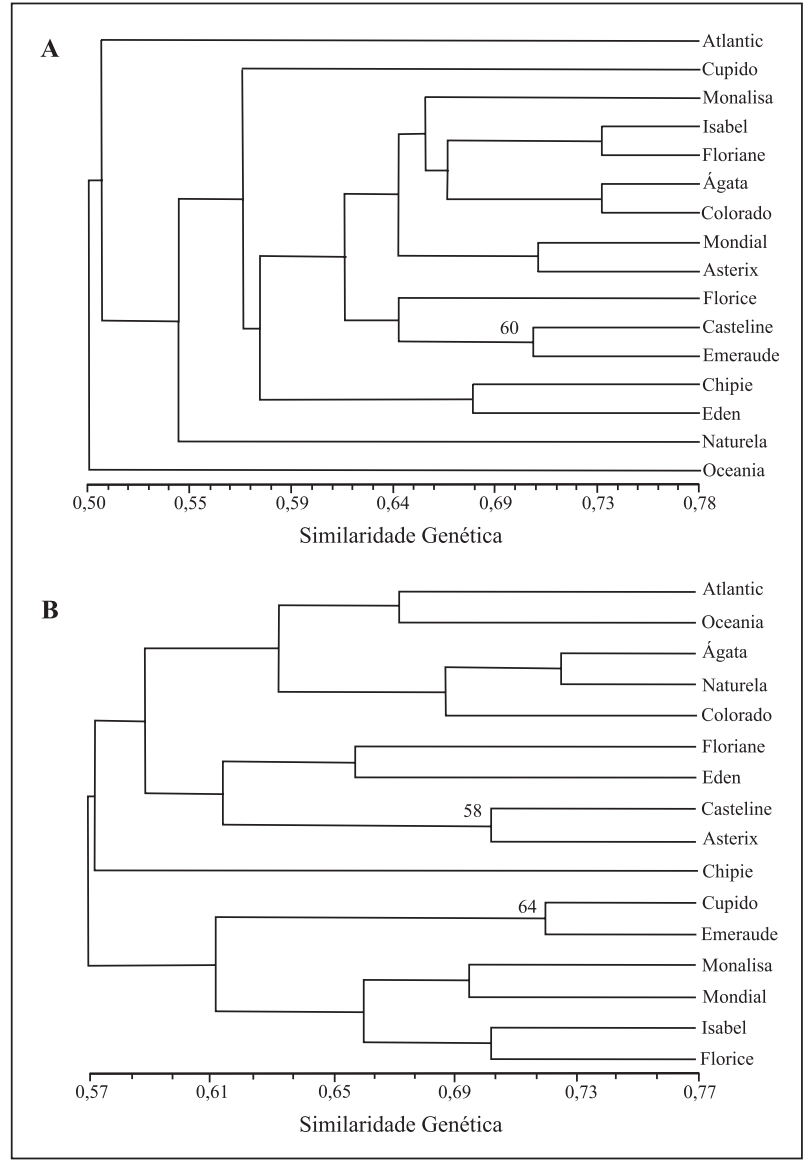

Figure 1. Dendrograms representing the genetic similarities obtained based on RAPD (A) and SSR (B) markers of 16 potato cultivars generated by UPGMA and bootstrap values above $50 \%$.

One possible explanation for this result could be the kind of information revealed by each molecular marker. RAPD markers are randomly distributed in the genome sampling preferentially intergenic regions. In contrast, SSR markers detect highly repetitive regions in the genome that can be derived from untranslated regions and introns, for example (Ghislain et al. 2006). In solanaceous species the microsatellite frequency was greater in the intron untranslated regions 5' (upstream of the gene) and 3' (downstream from the gene) (Smulders et al. 1997). Besides, each SSR primer amplifies theoretically one locus, while for RAPD one primer amplifies several loci.

Thus, the genetic divergence in the 16 potato varieties that are being made available to potato growers in Brazil was evaluated based on the RAPD and SSR markers, and a molecular profile was developed for their identification.

Crop Breeding and Applied Biotechnology 10: 204-210, 2010 


\title{
Caracterização molecular e diversidade genética de cultivares de batata utilizando marcadores SSR e RAPD
}

\begin{abstract}
RESUMO - Este trabalho teve como objetivo avaliar a divergência genética e identificar cultivares de batata por meio de marcadores RAPD e SSR. O DNA genômico de 16 cultivares de batata foi amplificado com primers RAPD e com pares de primers SSR. Os 25 primers RAPD geraram 92 bandas polimórficas e os 20 pares de primers SSR produziram 136 bandas polimórficas. Os dendrogramas gerados pela análise de agrupamento permitiram uma distinção genética das cultivares, entretanto não houve uma correlaçao entre os dendrogramas ao comparar os dois marcadores utilizados. Os valores de PIC demonstraram o alto conteúdo informativo dos primers utilizados e, com a utilização de 6 primers RAPD e de 3 pares de primers SSR, identificou-se as 16 cultivares de batatas. Dessa forma, por meio de marcadores moleculares RAPD e SSR foi possível avaliar a divergência genética e identificar as 16 cultivares comerciais de batata analisadas neste estudo.
\end{abstract}

Palavras-chave: Solanum tuberosum, $R A P D$, microssatélites, diversidade genética.

\section{REFERENCES}

Anderberg MR (1973) Cluster analysis for applications. Academic press, New York, 359p.

Ashkenazi V, Chani E, Levy D, Hillel J and Eeilleux RE (2001) Development of microsatellite markers in potato and their use in phylogenetic and fingerprinting analyses. Genome 62: 4450.

Bered F, Terra TF, Spellmeier M and Neto JFB (2005) Genetic variation among and within sweet corn populations detected by RAPD and SSR markers. Crop Breeding and Applied Biotechnology 5: 418-425.

Bianchi VJ, Fachinello JC and Schuch MW (2003) RAPDs na caracterização genético-molecular e no estudo da variabilidade genética de cultivares de ameixeira. Revista Brasileira de Fruticultura 25: 272-274.

Chakrabarti SK, Birhman RK and Pattanayak D (1998) Genetic similarity analysis and identification of Indian potato cultivars by random amplified polymorphic DNAs. Indian Journal of Experimental Biology 37: 1123-1128.

Chakrabarti SK, Pattanayak D, Sarkar D, Chimote VP and Naik PS (2006) Stability of RAPD fingerprints in potato: effect of source tissue and primers. Biologia Plantarum 50: 531-536.

Coelho ASG (2000) Programa Bood: avaliação dos erros associados a estimativas de distâncias/similaridades genéticas através do procedimento de bootstrap: versão 2.0. Editora UFG, Goiânia.

Coombs JJ, Frank LM and Souches DS (2004) An applied fingerprinting system for cultivated potato using simple sequence repeats. American Journal of Potato Research 81: $243-250$.

Crochemore ML, Nunes LM, Andrade A, Molinari HBCM and Vasconcellos ME (2004) Varietal identification of coffee seed by RAPD technique. Brazilian Archives of Biology and Technology 47: 7-11.
Cruz CD (2001) Programa GENES: aplicativo computacional em genética e estatística - versão Windows. Editora UFV, Viçosa, 648p.

Demeke T, Lynch DR, Kawchuck LM, Kozub GC and Armstrong JD (1996) Genetic diversity of potato determined by random amplified polymorphic DNA analysis. Plant Cell Reports 15: 662-667.

Dias LAS (1998) Análises multidimensionais. In Alfenas AC (ed.) Eletroforese de isoenzimas e proteínas afins: fundamentos e aplicações em plantas e microrganismos. Editora UFV, Viçosa, p. 405-475.

Feingold S, Lloyd J, Norero N, Bonierbale M and Lorenzen, J (2005) Mapping and characterization of new EST-derived microsatellites for potato (Solanum tuberosum L.). Theoretical Applied Genetic 111: 456-466.

Fontes PCR (2005) Cultura da batata. In Fontes PCR (ed.) Olericultura teoria e prática. Editora UFV, Viçosa, p.322343.

Ford R and Taylor PWJ (1997) The application of RAPD markers for potato cultivar identification. Australian Journal Agriculture Research 48: 1213-1217.

Garcia AF, Alberini JL, Zucchi MI and De Souza AP (2007) Microsatellite molecular markers in the cultivar identification of Brazilian soybean for human consumption. Crop Breeding and Applied Biotechnology 7: 155-164.

Ghislain M, Andrade D, Rodríguez F, Hijmans RJ and Spooner DM (2006) Genetic analysis of the cultivated potato Solanum tuberosum L. Phureja Group using RAPDs and nuclear SSRs. Theoretical Applied Genetic 113: 1515-1527.

Ghislain M, Rodriguez F, Villamon F, Nunez J, Waugh R and Bonierbale M (2000) Establishment of microsatellite assays for potato genetic identification. Research on Potato 167174. 
EA Rocha et al.

Hamester W and Hills U (2003) World catalogue of potato varieties. Que Pub, Indianapolis, 248p.

Harris PM (1978) The potato crop. Chapman \& Hall, London, 730p.

Kruskal JB (1964) Multidimensional scaling by optimizing goodness of fit to a no metric hypothesis. Psychometrika 29: 1-27.

Manly BFJ (1997) Randomization, bootstrap and Monte Carlo methods in biology. Chapman \& Hall, London, 281p.

Milbourne D, Meyer R, Bradshaw JE, Baird E, Bonar N, Provan J, Powell W and Waugh R (1997) Comparison of PCR-based marker systems for the analysis of genetic relationships in cultivated potato. Molecular Breeding 3: 127-136.

Murray MG and Thompson WF (1980) Rapid isolation of high molecular weight plant DNA. Nucleic Acids Research 8: 4321-4325.

Norero N, Malleville J, Huarte M and Feingold S (2002) Cost efficient potato (Solanum tuberosum L.) cultivar identification by microsatellite amplification. Potato Research 45: 131-138.

Provan J, Powell W and Waugh R (1996) Microsatellite analysis of relationships within cultivated potato (Solanum tuberosum). Theoretical and Applied Genetics 92: 1078-1084.
Rafalski DJA, Vogel JM, Morgante M, Powell W, Andre S and Tingey SV (1996) Generating and using DNA markers in plant. In Birren $\mathrm{B}$ and Lai $\mathrm{E}$ (eds.) Nonmammalian genomic analysis. A practical guide, New York, p. 75-134.

Rohlf FJ (2000) Programa NTSYS-pc: numerical taxonomy and multivariate analysis system: version 2.1. Exeter Software, New York, 83p.

Ross H (1986) Potato breeding - problems and perspectives. Verlag Paul Parey, Berlin, 132p.

Schneider K and Douches DS (1997) Assessment of PCR-based simple sequence repeats to fingerprint North American potato cultivars. American Potato Journal 74: 149-160.

Smulders MJM, Bredeeijer G, Rus-Kortekaas W, Arens P and Vosman B (1997) Use of short microsatellites from database sequences to generate polymorphisms among Lycopersicon esculentum cultivars and accessions of other Lycopersicon species. Theoretical and Applied Genetics 94: 264-272.

Sosinski B and Douches DS (1996) Using polymerase chain reaction-based DNA amplification to fingerprint North American potato cultivars. HortiScience 31: 130-133. 